\title{
BRITISH SURGERY IN THE SOUTH AFRICAN WAR: THE WORK OF MAJOR FREDERICK PORTER
}

\author{
by
}

EDWARD H. BENTON*

At THE onset of this century, two Boer states, the South African Republic, and the Orange Free State, with a combined force of about 87,000 men, were locked in a guerilla war against a British Empire military organization of nearly 450,000 men and 520,000 horses. The Boers' commando tactics enabled them to hold out from October 1899 to May 1902 . They were inevitably defeated, but only after an escalation of the war tempting many recent historians to label the conflict as the "British Vietnam".

The names of some of the individuals who witnessed that war are more familiar than the war itself. Winston Churchill, then a twenty-five-year-old newspaper correspondent, managed a hair-raising escape from the Boers and achieved world fame overnight. ${ }^{1}$ Cecil Rhodes, with a stake in local diamonds and politics, had an important personal concern in the outcome. Gandhi, then a young lawyer, worked on the battlefield as a stretcher-bearer or "body-snatcher" as the troops referred to his job. ${ }^{2}$ A. Conan Doyle, creator of Sherlock Holmes, was knighted in 1902 for two works defending British policy in the war in which he served as a civilian doctor. The names are familiar, but the war is not.

For the military, the Boer or "South African" War was a trial of new weaponry and of tactics. For surgeons, it was a trial of contemporary medicine's effectiveness in dealing with the damages inflicted by the latest instruments of human destruction.

For purposes of comparison, the following discussion of Boer War surgical experience includes many references to the nearly contemporaneous conflict, the Spanish-American War of 1898.

MAJOR PORTER AND THE BOER WAR SURGEON

Those British Boer War surgeons who observed the effects of their opponents' armaments were either military officers or civilians paid for their services. Fortunately, one of the former, Major Frederick J. W. Porter (1867-1950), kept a detailed day-today account of his battlefield experience in the form of a series of letters to his wife in England. Porter, who was commissioned as a captain in the Royal Army Medical Corps in 1891, was promoted to the rank of major in 1903. His diary begins on 22 October 1899, the day his ship left London for South Africa. The last entry in his

"Edward H. Benton, B.A., 38 East 63rd Street, New York, N.Y. 10021, U.S.A.

${ }^{1}$ Rayne Kruger, Good-bye Dolly Gray, London, Cassell, 1960, p. 167.

Ibid., p. 142. 


\title{
Edward H. Benton
}

journal is 4 April 1901, the day he left the battlefield to be treated for fever. ${ }^{3}$ The diary, which covers approximately eighteen months of the war, presents a vivid picture of the kind of medical treatment British soldiers received at the turn of the century. Porter's descriptions include the kinds of operations which were performed in field hospitals of the day.

Porter's diary abounds in interesting sidelights on his life as a field surgeon. In it he reveals himself as dedicated, but not lacking a sense of the absurd:

October 13, 1900. I didn't sleep a wink all night. First of all the dogs began to bark in the Kaffirs' location, which is quite close. Then the cocks began to crow as soon as the moon rose. After a bit, to my horror, one of my cocks began to crow like blazes and threatened to wake up the whole camp. This wasn't good enough, so I got out and wrung his neck. About half an hour after this one of the hens started a row, so I got up and killed her. I thought that this was surely the end of it, but it was not to be. I had 2 more cocks and they started after a bit. The result was no sleep, and 4 corpses in the morning ....

In an earlier letter he expresses the frustrating nature of guerilla warfare: "April 2,1900. I wish they would come out into the open and give us a chance of a big battle. As things are going at present we shan't finish the business for months."5 If Porter was not impressed with the kind of fighting he saw, he was with the guns being used. He felt that his own equipment for doing battle against disease was equally modern. "November 21, 1899. They are issuing lots of special equipment for this war, operating aprons, nail brushes, mosquito curtains, Berkfeld Filters, etc., in fact, doing as much as possible to keep up with the times." civilian life as dictated in Joseph Bryant's Operative surgery, published in 1900:

\begin{abstract}
A long aseptic rubber apron covered with a freshly sterilized, short-sleeved, white linen gown, reaching to the feet, are suitable for the surgeon, and can be supplemented by pinning in front a sterilized towel moistened with the antiseptic fluid. Each of the assistants should wear, at the least, a gown. ... The change of the underwear is a refinement that is not commonly practiced, but it adds much, indeed, to the after-comfort of the surgeon, and not a little to his personal safety in the instances of tedious effort in a hot room.?
\end{abstract}

In addition to his surgical instruments, drugs, and other medical supplies, the Boer War surgeon carried a small medical reference library. W. F. Stevenson's Wounds in war: the mechanism of their production and their treatment $(1897)^{8}$ was the Royal Army Medical Corps' principal text. By 1899, though, it was already outdated, since it did not include the latest device for locating bullets, the recently discovered Röntgen ray. ${ }^{\circ}$ Francis Freemantle, a civilian surgeon who volunteered for action in

After recovering from the fever, Porter was given command of the Medical Division at Bloemfontein General Hospital. He was seconded for service with the South African Constabulary from 1 July 1901 to 28 February 1905.

- Porter's diary, R.A.M.C. (Boer War), vol. 1, pp. 1-254, vol. 2, pp. 255-473, pp. 344-345. The original diary is located at the library of the London Hospital Medical College. A copy can be found in the muniments room of the Royal Army Medical College Library, Millbank, London.

Ibid., p. 153.

- Ibid., p. 21.

7 Joseph D. Bryant, Operative surgery, 2 vols., New York, D. Appleton, 1900, vol. 1, pp. 101-102.

- W. F. Stevenson, Wounds in war: The mechanism of their production and their treatment, New York, Longmans, Green, 1897.

- Francis E. Freemantle, Impressions of a doctor in khaki, London, John Murray, 1901, p. 29. 


\section{British surgery in the South African War}

South Africa, listed his collection of books as follows:

Technical: Erichsen's Surgery (2 vols.), Jacobson's Operations, Heath's Anatomy (the most important, especially because of pictures), Stevenson's Wounds in War, Osler's Medicine, Manson's Tropical diseases, Whitelegge's Public health . . . 10

THE FIELD HOSPITAL

As a medical officer, Major Porter was in command of a "field hospital". In the British R.A.M.C. system of battlefield medical organization this placed him right at the front line. Theoretically, a wounded man was transported by a "bearer company" from a "regimental aid post" to the field hospital over rough terrain via stretcher or wagon. The aid post was to serve a battalion as a first-aid station, but often the field hospital, positioned so close to the fighting, assumed the task of initial emergency care. Frederick Treves (1853-1923), an eminent civilian surgeon, described the 1899 British field hospital: "Each field hospital would be represented by a small central marquee, which formed an operating and dressing station, and a number of bell tents around it, which could accommodate, in all, about one hundred patients."11

The 1898 American field hospital differed little in appearance. George Kennan, a correspondent who accompanied Clara Barton in Cuba during the SpanishAmerican War, gave his impression of it: "The hospital, when I arrived, consisted of three large tents for operating-tables, pharmacy, etc.; another of similar dimensions for wounded officers; half a dozen small wall-tents for wounded soldiers; and a lot of 'dog-kennels', or low shelter-tents, for the hospital stewards, litter-bearers, and other attendants." 12

Furthermore, British "stationary hospitals" were located at intervals along the arterial railroad lines which traversed South Africa. ". . . Stationary Hospitals act as the connecting link between the Field-Hospitals at the front and the General Hospitals at the base. They have one hundred beds and four Medical Officers apiece, and can be moved up to an advanced base immediately on its occupation. General Hospitals, of course, with 520 beds, take longer to move. ..."13

Since the speed of medical transport in South Africa depended upon stretcherbearers and wagons drawn by oxen, mules, or horses, surgery was performed relatively close to the front line. Consequently, operations often took place in the field hospital, even though the function of this link in the medical chain was primarily that of temporary treatment.

\section{BOER WAR WEAPONRY}

The majority of surgical cases with which Porter dealt were the result of wounds produced by small-calibre weapons, an innovation brought to armies in $1888 .{ }^{14}$

Freemantle was a civilian surgeon on contract to the British Army.

10 Ibid., p. 530.

11 Frederick Treves, The tale of a field hospital, London, Cassell, 1900, p. 14.

12 George Kennan, Campaigning in Cuba, New York, Century, 1899, p. 131. Kennan (1845-1924) was an explorer, journalist, and author. He achieved a wide recognition as a correspondent in Cuba during the Spanish-American War.

18 Freemantle, op. cit., note 9 above, p. 58.

14 Theodore James, 'Gunshot wounds of the South African War', S. A. med. J., 9 October 1971, 45: 1090. 


\section{Edward H. Benton}

John DaCosta's textbook on surgery, published in 1900, described the "modern" rifle then in use:

A rifle whose calibre is less than 0.35 inch is known as a small-calibre rifle... The old Springfield rifle, of a calibre of 0.45 inch, projected a bullet with a velocity of thirteen hundred feet in a second. The Männlicher rifle, of a calibre of 0.25 to 0.32 inch, sends a bullet with a velocity of over two thousand feet a second. This bullet revolves with great velocity upon its own axis (two thousand times the first second) and is effective at several miles. The bullet of the modern rifle is conical, has a leaden core, and is hardened by being covered with a mantle or jacket of copper, steel, nickel. . . . ${ }^{16}$

Most Boer commandos used the 7-mm Mauser gun, while the British relied on the .303 inch calibre Lee-Metford. Both weapons fit DaCosta's description of the modern small-calibre rifle. The penetrating power of the Mauser was, at a distance of five yards, "capable of driving a bullet 55 inches into a log of pinewood." 16 The effect of this high-speed ogival bullet was less damaging to the victim compared to the mutilation produced by the old round ball in use prior to 1888 or the pointed bullet which followed in World War I. ${ }^{17}$

At the time of the Boer War, however, surgeons still did not know exactly what kinds of wounds to expect from the Mauser bullet. The only evidence for its "humanity" was a set of very limited data gleaned from the Spanish-American War, the Chilean civil war, and the British expedition to the Sudan. In fact, German experimenters predicted that the Mauser bullet would inflict a vicious wound.18

The observations of Nicholas Senn, Charles de Nancrede, and other American surgeons in the Spanish-American War were confirmed a year later, however, once the Boer War casualties began streaming in. Whereas the older projectile "was apt to lodge; was often deflected in the tissues; was flattened out on meeting with resistant structures, such as bone or cartilage, and after flattening became larger and tore and lacerated the soft parts and comminuted the bone," the new projectile was described as being, "apt to perforate, . . . rarely deflected, and ... so hard that its shape is generally but little altered on meeting with resistant structures."19

\section{MEDICAL EFFECTS OF NEW WEAPONRY}

The medical consequences of the Mauser were good news for the British surgeons, for the wounds were easy to treat and healed well. The jacket, casing, or plating of the bullet made the important difference. The external wound was usually a small incision which often healed by first intention, and which the careless observer might not even notice. Many previously fatal injuries healed remarkably well. "Joint injuries had extraordinarily good prognosis. A knee-joint could be completely transfixed by a Mauser bullet yet the worst it would do would be to injure the popliteal artery, and apart from a possible haemarthrosis, there was little other damage. Of

1s John Chalmers DaCosta, Modern surgery: general and operative, Philadelphia, W. B. Saunders, 1900 , p. 218.

10 John Laffin, Surgeons in the field, London, J. M. Dent, 1970, p. 203.

${ }^{17}$ Anthony Bowlby, The Bradshaw Lecture of 1915: wounds in war, Bristol, John Wright, 1916, p. 4.

10 James, op. cit., note 14 above, p. 1090.

10 DaCosta, op. cit., note 15 above, p. 219. 


\section{British surgery in the South African War}

92 knee-joint gunshot wound victims, 28 were returned to the front line." 20

The so-called "humanity" of the new bullet sparked absurd discussion of the future of war. Military experts talked of higher velocities coupled with smaller calibres to make war completely humanitarian. ${ }^{21}$ Others were not satisfied with the lack of "stopping power" of the Mauser-type weapon. They recommended the use of the "Dum Dum", particularly for combating "savages", who were infamous for suicidal charges. The report of an American military observer assigned to the South African Field Force reveals his disappointment:

I would lay special stress on the larger calibre, for the .303-nonexplosive will not stop a horse. I have seen horses, shot right through the neck or body by the small bullet, go all the afternoon under their riders and be entirely fit in three or four days. In my opinion the bullet is too merciful which permits of a large percentage of those wounded by it to return to the front within a few weeks, as the Mauser .27 and Lee-Metford .303 did in this war. ${ }^{22}$

Contrary to the American observer's pessimism, the Mauser was not always so humane. Although khaki material was cleanly perforated, fragments of the Highlanders' kilts were carried into the wound. This was the strongest surgical objection to their retention as part of the uniform in combat and led to their discontinuance as combat dress. Furthermore, range was found to be an important factor in determining the severity of a wound. "The bullet may lodge at long range, or if it hits a man after bounding from a stone. In Cuba 10 per cent of the wounded suffered from lodged bullets." 23

The high-velocity bullet also allowed for a type of casualty rarely seen before: multiple wounds. A bullet could completely pass through one man, decelerate, and end up inside a nearby soldier.

Range also dictated whether or not an "explosive effect" would occur.

This term does not mean that the bullet has exploded, but that its sudden impact against tissues has by waves of force caused extensive and distant damage. Explosive effects are seen most often at close range, when the velocity of the ball and the frequency of its rotation are most marked. A pistol-ball has no explosive action at all, and the old-time bullet possessed it only at very close range. The modern projectile always produces explosive effects up to five hundred yards. Up to thirteen hundred yards it produces them upon the skull and brain. At this distance a single small projectile may entirely destroy the cranium and brain. . . .24

Major Porter noted the effect of a very long-range bullet in the 3 March 1900 entry of his diary: "One of the mounted Infantry was shot last evening, he was going to water his horse and was shot through the head and killed, the range must have been over 2,000 yards, for the bullet lodged. ..."25

Humane or not, small arms were responsible for most wounds in the Boer War. Artillery played little part in wounding men. When shrapnel wounds did occur,

20 James, op. cit., note 14 above, p. 1091.

21 Ibid., p. 1093.

22 U.S. Adjutant General's Office, Reports on military operations in South Africa and China, no. 33, July 1901, Washington, Govt. Printing Office, pp. 80-81.

${ }^{2}$ DaCosta, op. cit., note 15 above, p. 220.

24 Ibid., pp. 219-220.

${ }^{25}$ Porter, op. cit., note 4 above, p. 123. 
though, they were often fatal, for sepsis frequently accompanied them. Even if they did heal, it was a much longer process than that associated with Mauser or LeeMetford wounds.

\section{THE FIRST FIELD DRESSING}

Once a soldier was wounded, the "first field dressing" was the initial step in medical treatment. In the Boer War, each soldier carried a packet containing one as part of his field equipment. The idea had originated during the Franco Prussian War of 1870 , and was officially introduced into the British army in 1884. The dressing used for the greater part of the South African War was designed in 1891. It contained:

1. A pad of gauze.

2. A pad of compressed flax charpie between layers of gauze.

3. A loose-wove bandage, $4 \$$ yards long.

4. A piece of waterproof jaconet to be applied outside the dressings, and

5. Two safety pins.

All the dressing materials in this packet were impregnated with a solution of 1 in 1,000 of corrosive sublimate. ${ }^{30}$

Towards the end of the campaign a replacement was issued with slightly different materials.

Both dressings shared a common problem which surgeon Porter discovered early in his work. On 2 January 1900, Porter criticized the dressing as follows:

I noticed today that these wounds which came in with a first field dressing on, and over which the piece of waterproof material had been applied, were quite moist and smelt offensively. Others on which the waterproof had not been applied, were quite sweet, dry and scabbed. The idea of a dry dressing is to make all discharges dry up at once and leave nothing for the germs to live in. ${ }^{27}$

Porter complained to the principal medical officer of the British army and he saw results, perhaps coincidentally, within a week. The army published an order forbidding the use of the waterproof cover, since many other field surgeons had also witnessed the drawback inherent in the waterproofing. Once the use of the "jaconet" was stopped, there was an appreciable improvement in the prevention of sepsis in the wounds.

There had been much controversy over the proper use of the first field dressing during the Spanish-American War. In his 1898 history of the War with Spain, Henry Keenan stated that:

To any one who knows the severe requirements of septic or antiseptic surgery, it must be obvious that the battlefield is no place for the first dressing. The medical experts hold that it is far better that a wounded man should wait three or four hours, if necessary, protected from the danger of hemorrhage by the windlass or circular bandage, which every litter bearer carries and knows how to apply, than to risk his life in the first dressing, that leaves anything to be desired."

26 W. F. Stevenson (ed.), Report on the surgical cases noted in the South African War, 1899-1902, London, Harrison, 1905, p. 270.

27 Porter, op. cit., note 4 above, pp. 59-60.

28 Henry F. Keenan, The conflict with Spain and the conquest of the Philippines, Philadelphia, P. W. Ziegler, 1898, pp. 374-375. 


\section{British surgery in the South African War}

By 1900, however, Nicholas Senn, an authority on American medicine during the Spanish-American War, was able to say that: "I am confident that the prompt first-aid dressing applied by well-instructed hospital corps men and litter-bearers will do more in the way of preventing wound infection than the delayed dressings in skilled hands." 29

During the Boer War, any British soldier was considered qualified to administer the first field dressing, and many lives were saved due to its effectiveness.

\section{TRANSPORT OF THE WOUNDED}

The second step in the line of medical treatment was by far the worst. The transport of the wounded from the battlefield to a hospital such as Porter's was as rough as the South African veldt. The difficulty of evacuating the wounded from the battlefield has always been, until the advent of air transport, dependent on terrain and land vehicles. In Cuba, the jungle prevented rapid movement of troops. Consequently, many of the wounded were never even found. After the battle for Santiago,

... there were some-those who had the strength when they fell to crawl through the cactus, the Spanish bayonet, and all manner of prickly and trailing plants into the deeper and more protected recesses of the jungle- who were never discovered at all until days, many days, had passed; and the gathering of vultures told where some poor fellow had died without care and without food, of his wounds or from starvation..$^{30}$

In the Boer War, there was no jungle, but the rugged veldt instead, with vast distances often separating the field of battle and the base hospital.

On the Boer side, the rescue system was quite efficient. Commandos went into battle in pairs, a father and son unit being typical, each responsible for evacuating the other, should he be incapacitated. This "buddy-system" resulted in a lower mortality from haemorrhage on the Boer side than on that of their enemy.

In The tale of a field hospital, Frederick Treves described the scene of the arrival of the wounded:

When I arrived the ambulances were already coming in - the dreary ambulances, each one with a load of suffering, misery, and death! Each waggon was drawn by ten mules and driven by a Kaffir, and over the dusty hood of each the red cross flag waved in the shimmering heat. They came along slowly, rocking and groaning over the uneven veldt, like staggering men, and each drew up at one or other of the little hospitals under the ridge. ${ }^{31}$

In many cases the ride from the battlefield to the Field Hospital contributed to the death of a wounded soldier.

When a member of Britain's parliament criticized the British army medical organization, he pointed out that military planning often did not take into account good medical judgement.

They were lifted out of their tents and put into rough ox-waggons-all typhoids and many of them

29 Nicholas Senn, Medico-surgical aspects of the Spanish-American War, Chicago, American Medical Association Press, 1900, p. 306.

${ }^{20}$ Stephen Bonsal, The fight for Santiago, New York, Doubleday \& McClure, 1899, p. 201.

21 Treves, op. cit., note 11 above, pp. 14-15. 


\section{Edward H. Benton}

dangerously ill-and then jolted across the veldt, which in this place is much broken by spruits and gullies. One case was in a state of 'haemorrhage' when moved. The order had come to evacuate the hospital; the medical officer had no choice but to obey; there were no ambulances. In three days 4 of these 20 were dead men.92

The importance of the medical section of the military to the success of a campaign was finally realized during and following the South African War. Senior medical officers in later wars were made an integral part of top decision-making staff.

A special problem was the transport of compound fracture cases. They were taken out of wagons and carried on stretchers whenever crossing a "drift" or other bad ground. However, the fracture was inevitably aggravated, and the pain was intense. The end result was too often the need for amputation, which then had to be performed in the field. Therefore, immediate treatment of compound fractures was recommended and, of course, avoidance of transport, if possible. ${ }^{33}$ Major Porter transported fracture cases with the help of "Morphia".

April 24, 1900. I found an officer of the 9th Lancers and a sergt., both with the worst compound fractures of the thigh that I have ever seen, also an abdominal wound; to these I gave a big dose of morphia which relieved them greatly. ... Then was told that we had to march 9 miles more and must take the wounded with us. The road was awful and we had several times to take out the bad cases and carry them over bad bits. ... The most fortunate thing was that I brought 2 oz. of the hypodermic injection of Morphia; only for that I don't know what I should have done. ..."en

TO TREAT OR NOT TO TREAT

The third stage in the treatment of a wounded soldier involved an important decision. If the patient had survived his journey to Porter's field hospital, Porter then had to decide whether or not to treat him. On the surface this may not sound like a difficult decision, but a great surgical debate between the "abstentionists" and "interventionists" had arisen in the 1890s.

The medical department of the U.S. army was criticized for not treating the wounded in the Spanish-American War, when, in fact, the doctors were practising what they believed to be "conservative" medicine.

The charge of neglect of the wounded, based upon the infrequent dressing of their wounds, has had no good basis, as it is an established rule of modern treatment that inspection and redressing are to be postponed until there is observed either staining of the dressing or rise of temperature. Stated generally, the less it is disturbed, the more quickly and kindly a wound heals. ${ }^{35}$

This philosophy was in sharp contrast to that of the Civil War surgeons thirty years before. They had been quick to probe for bullets and almost as eager to amputate, since they had little choice, considering the almost inevitable infection.

${ }^{82}$ W. L. A. Bartlett-Burdett-Coutts, The sick and wounded in South Africa: what I saw and said of them and of the army medical system, London, Cassell, 1900, p. 29.

${ }^{23}$ W. D. Wilson, Report on the medical arrangements in the South African War, London, Harrison, 1904, p. 100.

34 Porter, op. cit., note 4 above, pp. 171-172.

as Report of the commission appointed by the President to investigate the conduct of the War Department in the war with Spain, Washington, Govt. Printing Office, 1899, p. 76. 


\section{British surgery in the South African War}

In the Spanish-American War, the surgeon was much more hesitant to probe.

All of these cases tend to confirm previous observations to the effect that the small calibre bullet of the Mauser rifle, the one used exclusively by the Spaniards, causes wounds of the soft parts, which if left alone under the first dressing, will heal by primary intention in the course of a week or two, unless complicated by serious visceral injuries. ... I have seen the evil consequences following meddlesome probing. Such wounds are very susceptible to secondary infection caused by the use of the probe. ${ }^{36}$

Civilian textbooks of surgery in 1900 also advised against intervention, except in certain cases.

The surgeon must not feel it his duty to probe in all cases. In many cases it is better not to probe at all. Explore for the ball when sure that it has carried with it foreign bodies; when its presence at the point of lodgement interferes with repair; when it is in or near a vital region (as the brain); and when it is necessary to know the position of the bullet in order to determine the question of amputation or resection. If the wound is large enough, the finger is the best probe..$^{87}$

Boer War experience reaffirmed the British belief in conservative treatment. Whereas the old type of bullet made an abdominal case hopeless unless laparotomy was performed, the small-calibre bullet allowed for the possibility of recovery through conservative wound management. Laparotomy was attempted in South Africa and then abandoned due to a high mortality rate.

With regard to amputation, Stevenson, the British surgeon-general, said: "Any surgeon can amputate a limb-it is even on record that a sea-captain performed the operation when no more skilled person was available-but scientific surgery would be better exemplified by preserving it. Nevertheless, even conservative surgery must, on occasions, give way to the pressure of adverse circumstances when these cannot be overcome." ${ }^{38}$ Almost no amputations were performed for small-calibre gunshot wounds of an extremity during the Boer War, provided the antiseptic first field dressing had been immediately applied and the injured part had been completely immobilized. ${ }^{39}$ Amputations and resections were almost always the result of severe grenade or shrapnel wounds. ${ }^{40}$

An unfortunate consequence of the success with conservative surgery in the Boer War was the over-optimism of surgeons in approaching World War I wounds. They made the mistake of applying Boer War methods, which had worked so well in South Africa, to a very different situation. In a 1915 lecture on the experience of surgeons in World War I, Sir Anthony Bowlby was careful to point out the differences between the wounds in the Boer War and those in World War I: "But similar injuries with similar treatment in the present war would almost certainly have resulted in the death of the patients from gangrene, or at least in a prolonged suppuration and probable loss of the limb; and many surgeons who are familiar with South African conditions seem unable to realize the completely altered picture of the present war."41

36 Senn, op. cit., note 29 above, p. 163.

37 DaCosta, op. cit., note 15 above, p. 223.

${ }^{88}$ Stevenson, op. cit., note 8 above, p. 402.

s9 James, op. cit., note 15 above, p. 1092.

¿o Ibid., p. 1092.

¿1 Bowlby, op. cit., note 17 above, p. 4. 
THE OPERATING THEATRE

If Porter made the decision to operate, his field hospital carried the necessary equipment to do so. Operations in the year 1900 were not all done in a permanent operating theatre even in civilian life. Many operations were done on a kitchen table. William Keen and J. W. White's textbook of surgery prescribed the following preoperative preparations for the operation performed in an 1899 civilian household:

In the event of a serious operation the carpets should be removed, as well as all the hangings and upholstered furniture. The ceilings and side walls should then be brushed down with a towel saturated in bichloride. Papered walls require a dry towel. When the room is thus made empty and dusted, the floor and all the woodwork and furniture should be well scrubbed and washed with a solution of bichloride of mercury of the strength of 1:500. A plain kitchen table is the best for an operating table. ... .

Keen and White assume a good supply of water, an impossible assumption for a Boer War surgeon. "Five or six china washbowls and as many pitchers should be provided, two or three of them filled with distilled or cooled boiled water. Plenty of boiling water must be provided."43

Frederick Treves' description of a Boer War field hospital's operating tent brings out one of their major deficiencies: the lack of water in South Africa.

The marquee is small. It accommodates the operation table in the centre between the two poles, while along the sides are arranged the field panniers which serve as tables for instruments and dressings. . . . The floor of the tent is much-trodden grass, and, indeed, much-stained grass, for what drips upon it cannot be wiped up. There are no bright brass water-taps, but there is a brave display of buckets and tin basins. Water is precious, more precious than any other necessity, for every drop has to be brought by train from Frere. . . .4

\section{BULLET DETECTORS AND SKIAGRAPHS}

A valuable piece of equipment unavailable to field hospital surgeons was the revolutionary "skiagraph" apparatus. Prior to the discovery of the X-ray by Röntgen in 1895, surgeons depended on "bullet detectors". Stevenson's Wounds in war describes many types of probes, including an "electro-probe" with which a surgeon could hear the electrical contact with a metallic bullet through a microphone. ${ }^{45}$ All these were made obsolete by the Röntgen ray device, when it was available.

According to Surgeon-General Stevenson,

... the treatment of fractures in field hospitals is for the most part, of only a temporary and provisional character, and does not necessitate the use of X-rays; and the extraction of foreign bodies can be done with infinitely greater safety at fixed hospitals, where patients arrive from movable hospitals within a day or two of the receipt of their wounds, and where localisations and operations can be carried out at comparative leisure. ${ }^{40}$

The value of the X-ray was proven during the Spanish-American War. It was shown

${ }^{2}$ William Keen and J. William White (eds.), An American textbook of surgery, Philadelphia, W. B. Saunders, 1899, p. 1075.

as Ibid., p. 1075.

"Treves, op. cit., note 11 above, p. 20.

${ }^{45}$ Stevenson, op. cit., note 8 above, pp. 113-115.

46 Stevenson, op. cit., note 26 above, p. 276. 


\section{British surgery in the South African War}

to be much more accurate in locating bullets than any probes had been. The American army was very impressed with the device, if not over-zealous about it. "During the Terah expedition an X-ray apparatus was actually used so close to the fighting front that the operators were occasionally under gunfire. Such installations were definitely not recommended." 77 In 1900, DaCosta's civilian medical textbook recommended the fluoroscope or skiagraph as "the best means of discovering a bullet."48

However, neither the skiagraph apparatus nor its operators were foolproof at the time of the Boer War. Major Porter described a case in which he was told at a general hospital that X-rays did not reveal a fractured thigh that he had diagnosed. Porter was later found to be correct. The X-ray results had been wrong. ${ }^{40}$

\section{OPERATING EQUIPMENT}

Since Porter's field hospital was not equipped to do skiagraphic work, he sent many of his patients to the stationary and general hospitals where they could be X-rayed. This meant that he left many bullets inside wounded men, allowing the external wound to heal over. Aseptic surgery could be best accomplished at the general hospital, and Porter in most cases followed the conservative military doctrine. He only probed when he felt there was no other choice.

Porter's surgical supplies were adequate enough for him to attempt practically any operation of the day. Following the war, though, a report was issued reviewing British military medical arrangements. Deficiencies that field surgeons had noticed were enumerated.

... there should be at least one mechanic who has received training in the repair and upkeep of surgical instruments. ... an aspirator and an apparatus for saline transfusion is recommended .... the Committee are impressed with the excellence of the equipment contained in the United States Army medical and surgical chests .... . the equipment for issue to our field units might with advantage be modelled on these lines. ... Lamps and lanterns are all condemned, especially the operating lamp ... the hypodermic syringes are condemned chiefly on account of the softness of the needles. ... . Dressing trays (zinc) to be replaced by enamelled iron..$^{\text {so }}$

Porter's equipment was adequate, but left much room for improvement by contemporary civilian standards. The difficulty of adapting civilian surgical equipment to war conditions, though, was only overcome through trial and error. Many improvements were made during and immediately following the war.

\section{OPERATING CONDITIONS}

Adequate equipment did not guarantee good surgical conditions. By 1899 civilian surgery had advanced to a stage where aseptic surgery could be done routinely and quite successfully.

The statistics of all operations in the pre-Listerian days, as contrasted with those of the last twenty years, show that all those septic diseases which were rife in private and especially in

"7 W. Robert Nitske, The life of Wilhelm Conrad Röntgen: discoverer of the X-ray, Tucson, University of Arizona Press, 1971, p. 185.

¿ DaCosta, op. cit., note 15 above, p. 224.

- Porter, op. cit., note 4 above, p. 370.

so Wilson, op. cit., note 33 above, pp. 103, 105. 


\section{Edward H. Benton}

hospital practice, and slew their thousands and tens of thousands, have almost disappeared. Compound fractures, which then were among the most dangerous accidents, are now scarcely more dangerous than simple fractures, and the mortality-rate after amputation and abdominal section has fallen nearly to zero. ${ }^{.1}$

Much more elaborate safety precautions could be taken in civilian and military general hospital operating theatres than in the field hospital. A field hospital operating marquee would certainly not include a "water-bed", which was commonly used in civilian practice to prevent shock during the operation.

In some operating tables this is accomplished by having the top of the table composed of a series of tubes through which hot water circulates, but this necessitates a special table. An equally good plan is to have a large copper tray about 6 inches deep, and 5 feet in length, with a metal top, and tubes at the ends or the entrance and exit of hot water, which is kept circulating through it during the operation, Where this is not available, its place may be supplied by a water-bed or large water-pillow filled with water at a temperature of 110 degrees F. ${ }^{52}$

Even if such a cumbersome apparatus could have been carried around by a field hospital, it would have been impractical due to the absence of a good supply of water. Using warm water to keep the patient from going into shock would have been extravagant for a field hospital in South Africa. Often there was not even enough clean water to prepare proper antiseptic solutions.

Another, and a very important cause of the infection of wounds was on many occasions the impossibility of obtaining at the front water of a quality suitable for the preparation of antiseptic solutions, without an ample supply of which aseptic or antiseptic surgery is, of course, out of the question. The water on which the field hospitals and bearer companies' dressing stations had to depend for this purpose was often muddy and incapable of filtration through a Berkfeld filter, and, it could not be boiled for want of fuel. Naturally, under these circumstances, wounds became infected during the necessary dressings. ... .

One of Major Porter's experiences illustrates how the circumstances of war could create situations far from optimal for the surgeon operating in the field:

August 31, 1900. There was a shed about 50 feet long near the farm. It was used for drying skins under, and roughly divided into partitions. The wounded were put under it at one end, and the other was converted into an operating theatre. ... I I had 5 cases of fractured thighs, and splints had to be made and padded for 4 of these. One poor fellow had to have his thigh amputated, and another his arm. I found a piece of wainscoting, and one of the Boers who was a carpenter, made some splints. For padding we used up one of the ambulance cushions, and a Boer youth helped in teazing out the horsehair. There were about $\mathbf{2 0}$ men and several women and children about the place and they exhibited the greatest interest in the proceedings. . . . They had an excellent object lesson of the horrors of war, and one did not forget to point out the difference between the wounds made by the Mauser, and those made by Martini, Sporting and Explosive bullets. ... It was very hard on the amputation of the thigh case to have to put him into a jolting wagon 4 hours after the operation, but we had the others to think about as well, and we had to get back. ....

s1 Keen and White, op. cit., note 42 above, p. 1076.

62 W. Watson Cheyne and F. F. Burghard, A manual of surgical treatment, 7 vols., Philadelphia, Lea Brothers, 1899, vol. 1, p. 139.

st Stevenson, op. cit., note 26 above, p. 270.

sorter, op. cit., note 4 above, pp. 312-313. 


\section{British surgery in the South African War}

Porter then added a note explaining just how extraordinary conditions can become in the midst of war.

In operating on the thigh case-when the flaps had been retracted-I found that my saw (which was new and had probably been made in Germany) would not cut!! Lying on the ground was a big rip saw which the Boer women had lent me to make splints. I washed it in a bucket of water and sawed the bone with that. I flushed the stump with 1-1000 Perchloride of Mercury and sewed him up. He healed by primary union!! What luck!ss

\section{OPERATING TECHNIQUES}

The highlight of Major Porter's travels in the South African campaign was his encounter with Watson Cheyne, one of the leading surgeons of the day. Cheyne, who had worked with Lister, was the author of a well-known medical textbook, and represented the height of civilian surgical expertise. Porter asked for Cheyne's assistance in a case in which the only hope for survival was through amputation.

His letter to his wife, dated 26 April 1900, contained the following account of an operation in the field:

I had to dress the fracture cases, so I thought I would ask Watson Cheyne to see them. The sergt. stank and he had fever so he said that the leg ought to be amputated at the hip joint at once. He sent for his caravan which contains all his kit, operating tents, etc. We had the tent pitched and I got all ready. He had an acetylene lamp which made the place as bright as day. It was quite dark when we started. He had heard about my other case and advised me to do this by a new method, in which the femoral artery and veins were tied at first. . . . I got the femoral in 2 or 3 minutes and finished up in great style. . . . I am getting 500 men to carry the 41 worst cases on stretchers all the way ( 50 miles $)-12$ to a stretcher. I wanted to pump in strychnine as before, but Cheyne was playing about with 3 or 4 drop doses. ${ }^{.68}$

Cheyne's textbook of surgery, published in 1899 , advised the use of strychnine.

Of the very greatest value in the prevention or diminution of shock is the administration of strychnine before the commencement of the operation. In the case of an adult, a thirtieth of a grain should be injected subcutaneously just before the operation, or while the patient is being placed under the anesthetic; and during the course of the operation, if the pulse is beginning to fail, a second injection of a sixtieth of a grain may be administered. ${ }^{57}$

Porter, though, felt that more drastic action was called for.

The man was very bad and looked like dying, so I got 10 drops and gave it. He was astonished and said that it was a big dose, but I said that he wanted it. I wasn't going to let him have his way, he began to buck up at once. Then he thought he would try transfusion, and put $1 \frac{1}{2}$ pints of salt water into a vein!s8

Cheyne was an advocate of "transfusion", a procedure for which Porter was not even equipped. ${ }^{59}$ In Cheyne's manual of surgery the following procedure for "transfusion" was outlined:

ss Ibid., p. 314.

se Ibid., pp. 176-177.

s7 Cheyne and Burghard, op. cit., note 52 above, p. 140.

so Porter, op. cit., note 4 above, p. 177.

"T This procedure is now referred to as "infusion". The term "transfusion" now refers to the transfer of blood. 


\section{Edward H. Benton}

Hence, nowadays, the most common material for transfusion is the ordinary salt solution used in physiological work, that is to say, a 75 per cent solution of common salt. In practice, this is roughly about a teaspoonful of common salt to the pint of water. ... In introducing the saline solution, a vein is exposed. ... An oblique cut is then made through about half the calibre of the vessel between the two threads, and the nozzle of a suitable cannula is inserted into the opening. . . . Before the cannula is tied in a piece of india-rubber tubing is attached to it, and to this is fitted a glass funnel ... washed in carbolic acid, and then filled completely with salt solution and the tube clamped so as to expel all the air. ... The funnel is held from two to three feet above the level of the patient, the clamp is opened, and the fluid is allowed to flow gradually into the vein. ....

Blood transfusions, at that time, were thought to be harmful:

As regards the use of blood, either pure or mixed with phosphate of soda, it has been found that the red blood corpuscles introduced soon die, and have comparatively little effect as carriers of oxygen, and there is great difficulty and risk in introducing pure blood, chiefly owing to the formation of coagula in the instruments, or the detachment of coagula from them giving rise to pulmonary embolism. Even defibrinated blood is not free from this last objection. ${ }^{\circ 1}$

The hip patient, Porter was careful to point out, died (after an overland journey by wagon) "not of shock, but of acute blood poisoning." 62

Porter was impressed with Cheyne, though, and respected him as a teacher.

April 29, 1900 ... I told Cheyne that I would give anything to travel about with him and asked him to apply for me, in case Dalton had to give up. He said that he would do so. . . The experience I would get would be invaluable. ... He has a cart, and travels about with a complete kit for operations, tent lamp, etc., and lots of room for stores! ${ }^{\text {ss }}$

\section{RESULTS OF TREATMENT AND FACTORS INVOLVED}

Major Porter's experience was not exceptional, considering the overall picture of surgery in the Boer War. His daring amputations were few in number, and since they represented the most dramatic part of his surgical work, he gave them special attention in his diary. Like his fellow surgeons, Porter treated large numbers of wounded men who seemed to heal miraculously well. He lists those cases in a more statistical manner, for the lack of challenge they presented made them less exciting.

Küttner, a surgeon on the Boer side, stated that if the wounds from the British Lee-Metford rifle had not healed so well, it would have been impossible to handle the huge number of cases. ${ }^{64}$

The excellent surgical results achieved during the South African War have been attributed to a combination of factors. Spontaneous healing was a result of the high velocity of the modern bullet, the nature of the wound it produced, and the use of antiseptic procedures and the first field dressings on both the Boer and the British sides. ${ }^{65}$ C. T. Dent, in an article in the British Medical Journal of 1900, attributed much of the surgical success to the heat and dryness of the South African climate. ${ }^{86}$

${ }^{* 0}$ Cheyne and Burghard, op. cit., note 52 above, pp. 136-137.

"1 Ibid., p. 136.

'2 Porter, op. cit., note 4 above, p. 178.

es Ibid., p. 180.

os James, op. cit., note 14 above, p. 1093.

es Ibid., p. 1092.

c6 C. T. Dent, 'The Mooi River general hospital', Br. med. J., 1900, i: 772. 


\section{British Surgery in the South African War}

Yet Sir William MacCormac, writing in the Lancet in the same year, maintained that the climate was most unfavourable. The air was too often filled with dust and flies to maintain asepsis. ${ }^{67}$

As a consequence of the disastrous applications of Boer War surgical experience in the early part of World War I, analyses were made of the conditions which led to uncommon results.

One factor that played an important role was the difference in soil conditions. Anthony Bowlby's 1915 lecture on "Wounds in war" explained the situation:

In the first place I wish to point out how radically different are the fields of war in South Africa and in France. In the former we had to fight in a very thinly inhabited country, which supported few domestic animals, and which for the most part was quite uncultivated. The soil was dry and sandy, and in many places the rocks projected in the form of the well-remembered kopjes. The ground was uncontaminated by manure, and was to a great extent virgin soil. Rainfall was slight, cloudy days were few, and a hot sun with fresh breezes or strong winds dessicated the soil and prevented the growth of any luxuriant vegetation. The consequence of all these conditions was that, in the absence of decaying vegetable and animal matter, the soil was almost entirely free from all pyogenic organisms ... . except in the neighbourhood of the dwellings of man.8

The conditions were just the reverse in France during World War I, where the microorganisms in the soil contributed to the high incidence of sepsis. ${ }^{69}$ The types of wounds inflicted in the two wars were also very different. Most wounds in World War I were received at close range, when the bullet was at the height of its velocity, whereas in South Africa fighting was typically at long range. Short range bullets caused much more damage. ${ }^{70}$

World War I also brought a shift to artillery and a diminished importance of the rifle. In World War II, the mortar was responsible for sixty per cent of the casualties and sepsis and amputation again became common. ${ }^{71}$

\section{CONCLUSION}

Although surgery was very successful in the Boer War, the prevention of disease was not. "Though only 22,000 troops were treated by the R.A.M.C. for wounds, injuries and accidents through the thirty months of operations, twenty times that number were admitted to hospital with disease; 74,000 suffered from enteric and dysentery alone-both preventable diseases. Over 8,000 died from enteric."72

Porter wore a "cholera belt", ${ }^{73}$ but he also believed in the anti-typhoid vaccine which had been perfected by $1899 .^{74}$ Inoculation, however, was entirely on a volunteer basis, and no records were kept. The authorities concluded that the vaccine was of no value. ${ }^{75}$

' 7 Sir W. MacCormac, 'The wounded in the present war', Lancet, 1900, i: 1485.

68 Bowlby, note 17 above, op. cit., p. 3.

(o) Ibid., p. 4.

70 Ibid., p. 4.

71 James, op. cit., note 14 above, p. 1094.

72 Laffin, op. cit., note 16 above, p. 200.

${ }^{73}$ Porter, op. cit., note 4 above, p. 85 . It was believed that if the abdomen was kept warm, cholera could be prevented. The "cholera belt" was quite popular in the nineteenth century.

"Ibid., p. 9.

${ }^{75}$ Robert G. Richardson, Surgery: old and new frontiers, New York, Charles Scribner's Sons, 1968, p. 167. 
In the realm of surgery, though, the Boer War brought much hope, if not overconfidence. A combination of sound surgical knowledge, favourable environmental conditions, and small-calibre weapons contributed to a much higher recovery rate for bullet wounds than was possible in previous wars. Although they were operating under completely different conditions, surgeons in World War I made the mistake of anticipating results similar to those achieved in the Boer War. They were quick to learn, however, that the Boer War experience was exceptional, and that they again faced the battlefield surgeon's traditional challenge of controlling sepsis.

\section{SUMMARY}

Major Frederick Porter (1867-1950), a British military surgeon, served in the Boer or South African War of 1899. He kept a detailed account of his battlefield medical experiences in the form of a diary. In it he describes the treatment available to soldiers at the turn of the century, with particular emphasis on surgical practice. His successful treatment of wounds produced by the small-calibre, high-speed bullets of the Mauser rifle was normal for the war; similar results were obtained by Boer surgeons in treating wounds inflicted by the British Lee-Metford. Since the wounds healed so easily, controversy arose between "abstentionists" and "interventionists". The former advocated a conservative approach to wound management, which worked so well that few amputations were necessary, except in the cases of shrapnel wounds. Furthermore, the "skiagraph" apparatus, a relatively new device at the time, aided in the detection of bullets, once the wounded soldier reached the base hospital.

An unfortunate consequence of the Boer War surgeons' high success rate was the over-optimism carried into World War I. Surgeons in that war soon discovered that much of the Boer War surgical success could be attributed to the types of weapons used as well as to the favourable climatic and environmental conditions of South Africa. The shift from rifles to artillery and the abundance of infectious microorganisms in European soil forced World War I surgeons again to face the traditional battlefield problem of controlling sepsis.

\section{ACKNOWLEDGEMENTS}

The most important primary source was the unpublished diary of Major Frederick Porter. Mr. J. P. J. Entract, the librarian of the London Hospital Medical College, where the original diary is located, granted me permission to quote extensively from it. Several official reports on British military medical operations in South Africa were available for reference at the library of the Royal Army Medical College, Millbank, London. General Alastair MacLennan advised me on the technical aspects of surgery in the Boer War. Dr. George Rosen provided me with editorial advice in the final preparation of the article for publication. 